\title{
STRENGTH ABILITIES: ESTIMATION OF IMMEDIATE TRAINING EFFECT OF STRENGTH LOADS IN GIRLS AGED 7 YEARS
}

\author{
Khudolii O.M. ${ }^{1}$, Ivashchenko O.V. ${ }^{2}$, Iermakov S.S. ${ }^{3}$, Nosko Yu.M. ${ }^{4}$, Marchenko S.I. ${ }^{5}$ \\ ${ }_{1,2,5}$ H.S. Skovoroda Kharkiv National Pedagogical University \\ ${ }^{3}$ Gdansk University of Physical Education and Sport \\ ${ }^{4}$ Taras Shevchenko National University of "Chernihiv Collegium"
}

Corresponding Author: Khudolii O.M., e-mail: khudolii.oleg@gmail.com

Accepted for Publication: June 20, 2019

Published: June 25, 2019

DOI:10.17309/tmfv.2019.2.06

\begin{abstract}
The study purpose was to experimentally substantiate technological approaches to estimating training effects of strength loads in girls aged 7 years.

Materials and methods. The study participants were girls aged 7 years $(n=40)$. The children and their parents were fully informed about all the features of the study and gave their consent to participate in the experiment. To solve the tasks set, theoretical and empirical methods were used: analysis and generalization of scientific and methodological literature; modeling, pedagogical observation and experiment, methods of mathematical experiment planning ( $2^{\mathrm{k}}$ type FFE).

Results. The study results show that in the proposed matrix of the $2^{2}$ type full factorial experiment design, the chosen step of variation of factors is sufficient to study the influence of different modes of strength exercises on the dynamics of ITE in girls aged 7 years.

Conclusions. At station 1 (exercises to strengthen arms and shoulders), the ITE in girls aged 7 is most influenced by the interaction between the number of repetitions in a set and the rest interval $\left(\mathrm{x}_{1} \mathrm{x}_{2}\right)-83 \%$, the number of repetitions in a set $\left(\mathrm{x}_{1}\right)-15 \%$; at station 2 (exercises to strengthen abdominal muscles), it is most influenced by the number of repetitions in a set $\left(\mathrm{x}_{1}\right)-48.5 \%$, the rest interval $(\mathrm{x} 2)-48.5 \%$; at station 3 (exercises to strengthen back muscles) - by the rest interval $\left(\mathrm{x}_{2}\right)-82 \%$; at station 4 (exercises to strengthen leg muscles) - by the rest interval $\left(\mathrm{x}_{2}\right)-92 \%$.

At stations 1-3, to strengthen the ITE, it is necessary to increase the number of repetitions in a set and the duration of the rest interval, at station 4 , it is necessary to increase the number of repetitions in a set and to reduce the duration of the rest interval.

Keywords: girls, full factorial experiment design, immediate training effect, strength loads.
\end{abstract}

\section{Introduction}

The issue of strength abilities development in children and adolescents is regarded as a condition for improving the effectiveness of a school physical education class (Khudolii \& Titarenco, 2013; Ivashchenko \& Cieślicka, 2017; Cieślicka \& Ivashchenko, 2017). Research has found that learning effectiveness improves if motor abilities integrate into motor skills (Khudolii, 2011; Ivashchenko, 2017).

Strength development in a school lesson, in contrast to the sport of higher achievements (Verkhoshanskyy, 1985), is considered a necessary condition for improving the learning process (Ivashchenko \& Yermakova, 2015)

(C) Khudolii O.M., Ivashchenko O.V., Iermakov S.S.,

Nosko Yu.M., Marchenko S. I., 2019. and the basis of motor abilities development (Khudolii \& Ivashchenko, 2014; Ivashchenko, Cieślicka, Khudolii \& Iermakov, 2014).

The effectiveness of strength development is significantly influenced by the modes of strength exercises (Titarenko, 2010; Khudolii, 2011), as well as the interaction of training effects (Khudolii, 2011). The programming of strength development is based on the estimation of training effects (Khudolii, Ivashchenko, Iermakov \& Rumba, 2016, Lopatiev, Ivashchenko, Khudolii, Pjanylo, Chernenko \& Yermakova, 2017) and determination of the optimal number of strength training lessons (Khudolii, 2011; Khudolii \& Titarenco, 2013).

One of the methods for obtaining objective information about the body state dynamics, depending 

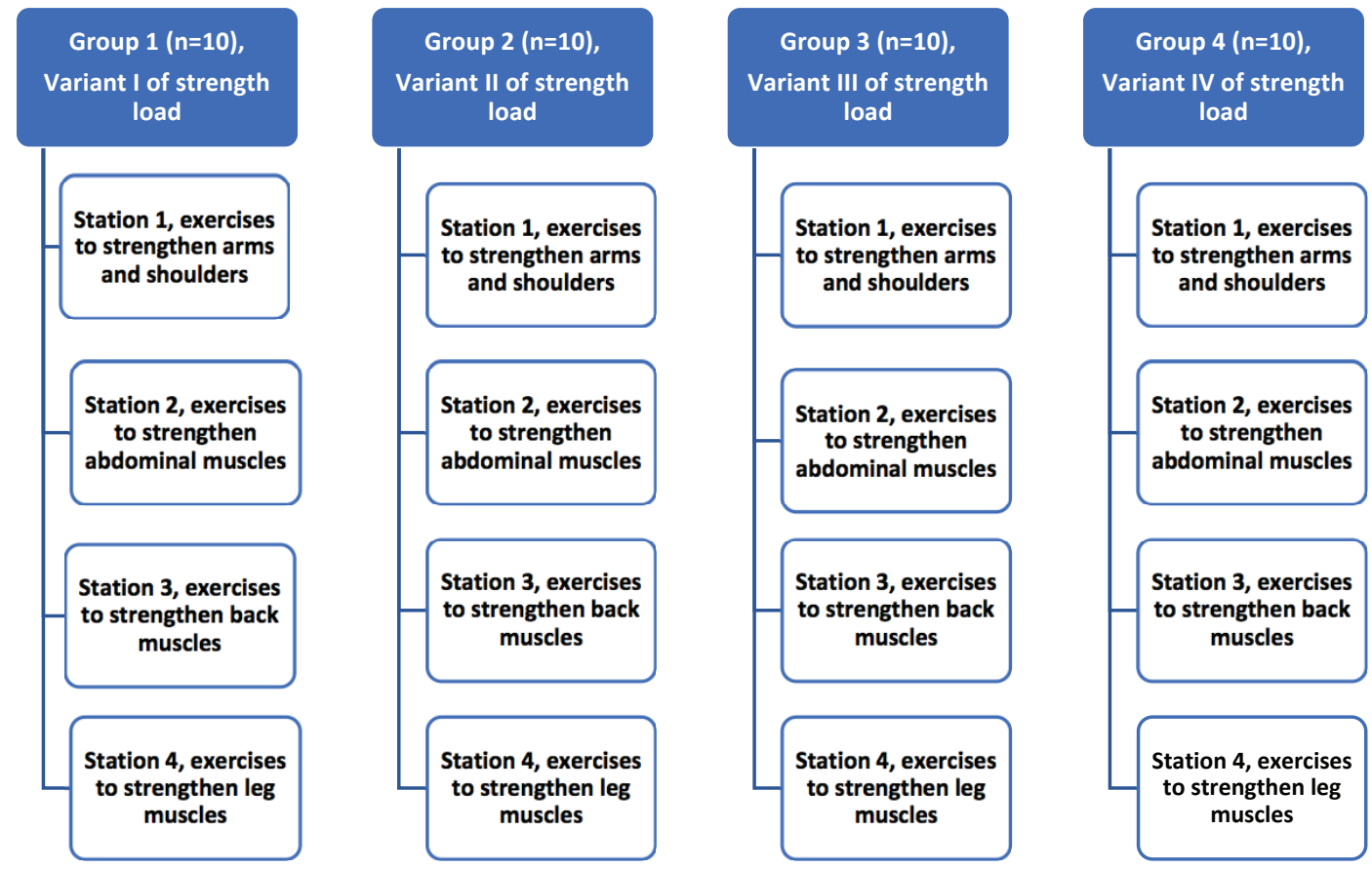

Figure 1. Scheme of organizing a pedagogical experiment

on the number of repetitions of physical exercises and rest intervals is modeling. In their studies, Lopatiev, Ivashchenko, Khudolii, Pjanylo, Chernenko and Yermakova (2017), Khudolii, Ivashchenko, Iermakov and Rumba (2016) developed conceptual approaches to modeling the learning process and motor abilities development in physical education and sport. The researchers describe the models of motor abilities development in children and adolescents, which can be used for current and final control of preparedness (Ivashchenko \& Yermakova, 2015; Ivashchenko \& Cieślicka, 2016; Cieślicka \& Ivashchenko, 2016). It was found that current control over the level of motor preparedness can be performed on the basis of regression models that describe the dependence of physical education on physical exercises modes (Ivashchenko, 2016; Ivashchenko \& Kapkan, 2016; Ivashchenko, Khudolii, Yermakova, Iermakov, Nosko, M. \& Nosko, Y., 2016). Scientific literature provides the results from the analysis of seven-year-old boys' and girls' body reaction on strength loads, reveals the peculiarities of the formation of training effects, depending on the mode of strength exercises (Cieślicka \& Ivashchenko, 2017; Ivashchenko \& Cieślicka, 2017).

In this regard, the question arises as to the relevance of developing a method for evaluating training effects in the process of strength development in girls aged 7 years.

The study purpose was to experimentally substantiate technological approaches to estimating training effects of strength loads in girls aged 7 years.

\section{Materials and methods}

\section{Study participants}

The study participants were girls aged 7 years $(n=40)$. The children and their parents were fully informed about all the features of the study and gave their consent to participate in the experiment.

\section{Study organization}

To solve the tasks set, theoretical and empirical methods were used: analysis and generalization of scientific and methodological literature; modeling, pedagogical observation and experiment, methods of mathematical experiment planning ( $2^{\mathrm{k}}$ type FFE).

To determine the dynamics of strength training effects in girls aged 7 years, the study carried out an experiment according to the plan given in Table 1 . Variant I of the combined method was used to strengthen arm and shoulder muscles (place I), abdominal muscles (place II), back muscles (place III), and leg muscles (place IV). At each place, the following methods were used: dynamic effort method, maximal effort method, isometric effort method, repeated effort method. The modes of performance for each group, for the indicated places are given in Table 1 (see Table 1, Figure 1).

During the experiment, the study recorded the results of the following tests: 1. Push-ups. 2. Speed push-ups, 3 times. 3 . Sit-ups in 30 seconds. 4 . Trunk lift in 10 seconds. 5 . Standing long jump. 
Table 1. Factorial design in studying the influence of different modes of the combined method of strength development (variant I) in primary school children $\left(X_{1}-\right.$ number of repetitions in a set; $X_{2}$ - rest interval, s)

\begin{tabular}{llcc}
\hline $\begin{array}{c}\text { No. of strength } \\
\text { load variant }\end{array}$ & \multicolumn{1}{c}{ Method } & $\boldsymbol{X}_{1}$ & $\boldsymbol{X}_{2}$ \\
\hline \multirow{4}{*}{ I } & Dynamic effort method & 3 & 30 \\
& Maximal effort method & 1 & 30 \\
& Isometric effort method & 3 & 30 \\
& Repeated effort method & 6 & 30 \\
\hline \multirow{3}{*}{ II } & Dynamic effort method & 5 & 30 \\
& Maximal effort method & 3 & 30 \\
& Isometric effort method & 5 & 30 \\
III & Repeated effort method & 12 & 30 \\
\hline \multirow{4}{*}{ IV } & Dynamic effort method & 3 & 60 \\
& Maximal effort method & 1 & 60 \\
& Isometric effort method & 3 & 60 \\
& Repeated effort method & 6 & 60 \\
\hline
\end{tabular}

On the first day before the experiment, the study recorded the results of Test 2 "Speed push-ups, 3 times", Test 1 "Push-ups", Test 3 "Sit-ups in 30 seconds", Test 4 "Trunk lift in 10 seconds", Test 5 "Standing long jump". After performing the exercises at place I - Tests 2, 1; at place II - Test 3; at place III - Test 4 ; at place IV Test 5. After the lesson - Tests 2, 1, 3, 4 .

\section{Statistical analysis}

The study analyzed the increase in the results of the above-mentioned tests. The Yates algorithm was used to calculate regression coefficients.

\section{Results}

Tables 2 and 3 show the results of the $2^{2}$ type full factorial experiment.

The analysis of the regression equations given in Table 2 made it possible to determine the influence of strength loads on the immediate training effect (ITE) of different modes of exercises in girls aged 7 . After training at stations $1-4$, the following data were obtained:

after training at station 1 - exercises to strengthen arms and shoulders - the ITE is most influenced by the interaction between the number of repetitions in a set and rest interval $\left(x_{1} x_{2}\right)$, number of repetitions in a set $\left(x_{1}\right)$ and rest interval $\left(x_{2}\right)$. To strengthen the ITE, it is necessary to increase the number of repetitions in a set and the duration of the rest interval;

after training at station 2 - exercises to strengthen abdominal muscles - the ITE is most influenced by the number of repetitions in a set $\left(x_{1}\right)$, rest interval $\left(x_{2}\right)$ and the interaction between the number of repetitions in a set and rest interval $\left(x_{1} x_{2}\right)$. To strengthen the ITE, it is necessary to increase the number of repetitions in a set and the duration of the rest interval;

after training at station 3 - exercises to strengthen back muscles - the ITE is most influenced by the rest interval $\left(x_{2}\right)$, the interaction between the number of repetitions in a set and rest interval $\left(x_{1} x_{2}\right)$ and the number of repetitions in a set $\left(x_{1}\right)$. To strengthen the ITE, it is necessary to increase the number of repetitions in a set and the duration of the rest interval;

after training at station 4 - exercises to strengthen leg muscles - the ITE is most influenced by the rest interval $\left(x_{2}\right)$, the interaction between the number of repetitions in a set and rest interval $\left(x_{1} x_{2}\right)$ and the number of repetitions in a set $\left(x_{1}\right)$. To strengthen the ITE, it is necessary to increase the number of repetitions in a set and to reduce the duration of the rest interval.

The dispersion analysis given in Table 2 made it possible to determine the percentage influence of the factors on the immediate training effect (ITE) of different modes of exercises in girls aged 7. After training at stations $1-4$, the following data were obtained:

after training at station 1 - exercises to strengthen arms and shoulders - the ITE is most influenced by the interaction between the number of repetitions in a set and rest interval $\left(x_{1} x_{2}\right),-83 \%$, the number of repetitions in a set $\left(x_{1}\right)-15 \%$. To strengthen the ITE, it is necessary to increase the number of repetitions in a set and the duration of the rest interval;

after training at station 2 - exercises to strengthen abdominal muscles - the ITE is most influenced by the number of repetitions in a set $\left(x_{1}\right)-48.5 \%$, rest interval $\left(x_{2}\right)-48.5 \%$. To strengthen the ITE, it is necessary to increase the number of repetitions in a set and the duration of the rest interval;

after training at station 3 - exercises to strengthen back muscles - the ITE is most influenced by the rest interval $\left(x_{2}\right)-82 \%$. To strengthen the ITE, it is necessary to increase the number of repetitions in a set and the duration of the rest interval;

after training at station 4 - exercises to strengthen leg muscles - the ITE is most influenced by the rest interval $\left(x_{2}\right)-92 \%$. To strengthen the ITE, it is necessary to increase the number of repetitions in a set and to reduce the duration of the rest interval.

\section{Discussion}

The paper assumed that a full factorial experiment would allow to determine the influence of strength loads on the immediate training effect (ITE) of different modes of exercises in girls aged 7 years. The study results show that in the proposed matrix of the $2^{2}$ type full factorial experiment design, the chosen step of variation of factors is sufficient to study the influence of 
Table 2. Models of influence of different strength training modes on the change in the immediate training effect in girls aged $7(n=40)\left(x_{1}-\right.$ number of repetitions in a set, $x_{2}-$ rest interval). The first variant of the combined method of strength development.

\begin{tabular}{|c|c|c|c|c|c|c|}
\hline \multirow{2}{*}{$\begin{array}{l}\text { Place of } \\
\text { training }\end{array}$} & \multirow{2}{*}{ Test } & \multirow{2}{*}{$\begin{array}{c}\text { Conditions of } \\
\text { recording }\end{array}$} & \multirow{2}{*}{ Regression equations } & \multicolumn{3}{|c|}{ Ratio of mean squares } \\
\hline & & & & $x_{1}$ & $x_{2}$ & $x_{1} x_{2}$ \\
\hline \multirow{2}{*}{ Station I } & 1. "Push-ups" & $\begin{array}{l}\text { after performing the } \\
\text { exercises }\end{array}$ & $\mathrm{Y}=-0.725-0.075 x_{1}-0.025 x_{2}-0.175 x_{1} x_{2}$ & 15 & 2 & 83 \\
\hline & 2. "Speed push-ups, 3 times" & $\begin{array}{l}\text { after performing the } \\
\text { exercises }\end{array}$ & $Y=0.183+0.053 x_{1}-0.013 x 1-0.023 x_{1} x_{2}$ & 81 & 5 & 14 \\
\hline Station II & 3. "Sit-ups in 30 seconds" & $\begin{array}{l}\text { after performing the } \\
\text { exercises }\end{array}$ & $\mathrm{Y}=-1.15-0.2 x_{1}-0.2 x_{2}+0.05 x_{1} x_{2}$ & 48.5 & 48.5 & 3 \\
\hline Station III & 4. "Trunk lift in 10 seconds" & $\begin{array}{l}\text { after performing the } \\
\text { exercises }\end{array}$ & $\mathrm{Y}=-0.5-0.1 x_{1}-0.3 x_{2}+0.1 x_{1} x_{2}$ & 9 & 82 & 9 \\
\hline Station IV & 5. "Standing long jump" & $\begin{array}{l}\text { after performing the } \\
\text { exercises }\end{array}$ & $\mathrm{Y}=-0.6-0.5 x_{1}+1.7 x_{2}+0.1 x_{1} x_{2}$ & 8 & 92 & 0 \\
\hline
\end{tabular}

Table 4. Modes of strength exercises (combined method of strength development, variant I) for girls aged 7 years $\left(X_{1}-\right.$ number of repetitions in a set; $X_{2}$ - rest interval, s)

\begin{tabular}{|c|c|c|c|}
\hline \multirow[b]{2}{*}{ Stations } & \multirow[b]{2}{*}{ Method } & \multicolumn{2}{|c|}{ Mode of exercises } \\
\hline & & $\begin{array}{c}X_{1}-\text { number of } \\
\text { repetitions in a set }\end{array}$ & $X_{2}-$ rest interval, $s$ \\
\hline \multirow{4}{*}{$\begin{array}{l}\text { Station } 1 \text {, exercises to strengthen arms } \\
\text { and shoulders }\end{array}$} & Dynamic effort method & 5 & 60 \\
\hline & Maximal effort method & 3 & 60 \\
\hline & Isometric effort method & 5 & 60 \\
\hline & Repeated effort method & 12 & 60 \\
\hline \multirow{4}{*}{$\begin{array}{l}\text { Station 2, exercises to strengthen } \\
\text { abdominal muscles }\end{array}$} & Dynamic effort method & 5 & 60 \\
\hline & Maximal effort method & 3 & 60 \\
\hline & Isometric effort method & 5 & 60 \\
\hline & Repeated effort method & 12 & 60 \\
\hline \multirow{4}{*}{$\begin{array}{l}\text { Station } 3 \text {, exercises to strengthen back } \\
\text { muscles }\end{array}$} & Dynamic effort method & 5 & 60 \\
\hline & Maximal effort method & 3 & 60 \\
\hline & Isometric effort method & 5 & 60 \\
\hline & Repeated effort method & 12 & 60 \\
\hline \multirow{4}{*}{$\begin{array}{l}\text { Station } 4 \text {, exercises to strengthen leg } \\
\text { muscles }\end{array}$} & Dynamic effort method & 5 & 30 \\
\hline & Maximal effort method & 3 & 30 \\
\hline & Isometric effort method & 5 & 30 \\
\hline & Repeated effort method & 12 & 30 \\
\hline
\end{tabular}

different modes of strength exercises on the dynamics of ITE in girls aged 7 years (Table 1).

Regression equations and dispersion analysis make it possible to specify and select the most effective variants of exercises modes for obtaining the ITE (Table 2).

The optimal modes of strength exercises (combined method of strength development, variant I) for girls aged 7 years are given in Table 4 . At stations $1-3$, to strengthen the ITE, it is necessary to increase the number of repetitions in a set and the duration of the rest interval, at station $4-$ it is necessary to increase the number of repetitions in a set and to reduce the duration of the rest interval.

These findings supplement the data obtained by Ivashchenko and Cieślicka (2017), Cieślicka and Ivashchenko (2017) on the effectiveness of using factorial designs when studying strength training effects in children; and the data of Ivashchenko, Khudolii, Iermakov, Chernenko and Honcharenko (2018), Khudolii and Marchenko (2007) on the reliability of the obtained regression equations for modeling the process of motor skills and motor abilities development in schoolchildren.

The validity of using a $2^{\mathrm{k}}$ type full factorial experiment is confirmed by the data of Correa, Grima and Tort-Martorell $(2009,2012)$. The main purpose of designs is to neutralize the influence of unknown factors, the authors recommend using designs with three and four factors. The results of the above-mentioned studies (Tables 2, 3) demonstrate the effectiveness of using a 22 FFE when studying the ITE of strength loads in girls aged 7 years.

The obtained results specify the conceptual approaches to experiment planning in studying the effectiveness of children's physical education, factorial 
designs are objective tools for obtaining data for the calculation of regression models of training effects in children (Khudolii, 2011; Ivashchenko, 2016).

\section{Conclusions}

The study results show that in the proposed matrix of the $2^{2}$ type full factorial experiment design, the chosen step of variation of factors is sufficient to study the influence of different modes of strength exercises on the dynamics of ITE in girls aged 7 years.

At station 1 (exercises to strengthen arms and shoulders), the ITE in girls aged 7 is most influenced by the interaction between the number of repetitions in a set and the rest interval $\left(x_{1} x_{2}\right)-83 \%$, the number of repetitions in a set $\left(x_{1}\right)-15 \%$; at station 2 (exercises to strengthen abdominal muscles), it is most influenced by the number of repetitions in a set $\left(x_{1}\right)-48.5 \%$, the rest interval $\left(x_{2}\right)-48.5 \%$; at station 3 (exercises to strengthen back muscles) - by the rest interval $\left(x_{2}\right)-$ $82 \%$; at station 4 (exercises to strengthen leg muscles) - by the rest interval $\left(x_{2}\right)-92 \%$.

At stations 1-3, to strengthen the ITE, it is necessary to increase the number of repetitions in a set and the duration of the rest interval, at station $4-$ it is necessary to increase the number of repetitions in a set and to reduce the duration of the rest interval.

\section{Conflict of interest}

The author declares no conflict of interests.

\section{References}

Khudolii, O.M. (2011).Teoretiko-metodichni zasadi sistemi pidgotovki iunikh gimnastiv 7-13 rokiv. Dokt. Diss. [Theoretical-methodic principles of system of junior, 7-13 yrs. age, gymnasts' training Dokt. Diss.], Kiev; 2011 (in Ukrainian)

Khudolii, O., \& Titarenco, A. (2013). The effectiveness of development programming strength in primary school children. Pedagogics, Psychology, Medical-Biological Problems of Physical Training and Sports, 17(7), 83-88. Retrieved from https://www.sportpedagogy.org.ua/ index.php/PPS/article/view/517.

Ivashchenko, O.V, \& Yermakova, T.S. (2015). Structural model of in-group dynamic of 6-10 years old boys' motor fitness. Pedagogics, psychology, medical-biological problems of physical training and sports, 19(10), 24-32. doi:10.15561/18189172.2015.1004

Titarenko, A. A. (2010). Osoblivosti rozvitku ruhovih zdibnostey u divchatok molodshogo shkilnogo viku. Teoriâ Ta Metodika Fizičnogo Vihovannâ, (9), 3-13. Retrieved from https://www.tmfv.com.ua/journal/ article/view/652 (in Ukrainian)

Verkhoshanskyy, Yu.V. (1985). Prohrammyrovanye y orhanyzatsyya trenyrovochnoho protsessa
[Programming and organization of the training process]. M.: Fyzkul'tura y sport, 176. (in Russian)

Lopatiev, A., Ivashchenko, O., Khudolii, O., Pjanylo, Y., Chernenko, S. \& Yermakova T. (2017). Systemic approach and mathematical modeling in physical education and sports. Journal of Physical Education and Sport (JPES), 17(1), suplement, 146-155. https://doi. org/10.7752/jpes.2017.s1023

Khudolii, O.M., Ivashchenko, O.V., Iermakov, S.S., \& Rumba, O.G. (2016). Computer simulation of junior gymnasts' training process. Science of Gymnastics Journal, 8(3), 215-228.

Ivashchenko, O., \& Cieślicka, M. (2016). Discriminant analysis in the classification of the preparation strength girls 11-12 year. Journal of Education, Health and Sport, 6(8), 888-897. https://doi.org/10.5281/zenodo.229884

Cieślicka, M., \& Ivashchenko, O. (2016). Discriminant analysis method to determine the power of the boys 1112 year. Journal of Education, Health and Sport, 6(10), 721-729. https://doi.org/10.5281/zenodo.229911

Ivashchenko, O.V. (2016). Methodic of pedagogic control of 16-17 years' age girls' motor fitness. Pedagogics, psychology, medical-biological problems of physical training and sports, 20(5), 26-32. https://doi. org/10.15561/18189172.2016.0504

Cieślicka, M., \& Ivashchenko, O. (2017). Features of formation of the cumulative effect of power loads in boys 7 years old. Journal of Education, Health and Sport, 7(1), 198-208. https://doi.org/10.5281/zenodo.250599

Ivashchenko, O., \& Cieślicka, M. (2017). Features of evaluations of power loadsin boys 7 years old. Journal of Education, Health and Sport, 7(1), 175-183. https:// doi.org/10.5281/zenodo. 249184

Ivashchenko, O.V. (2017). Special aspects of motor fitness influence on level of 11-13 years' age girls' physical exercises' mastering. Pedagogics, Psychology, Medical-Biological Problems Of Physical Training And Sports, 21(1), 11-17. https://doi. org/10.15561/18189172.2017.0102

Khudolii, O. M., \& Ivashchenko, O.V. (2014). Features functional coordination force preparedness and girls grades 7-8. Teoriâ Ta Metodika Fizičnogo Vihovannâ, (2), 15-21. https://doi.org/10.17309/tmfv.2014.2.1095

Ivashchenko, O.V., Cieślicka, M., Khudolii, O. M., \& Iermakov, S. S. (2014). Modeling power fitness girls grades 6-7. Teoriâ Ta Metodika Fizičnogo Vihovannâ, (3), 10-16. https://doi.org/10.17309/tmfv.2014.3.1103 (in Ukrainian)

Ivashchenko, O., Khudolii, O., Yermakova, T., Iermakov, S., Nosko, M., \& Nosko, Y. (2016). Factorial and discriminant analysis as methodological basis of pedagogic control over motor and functional fitness of 14-16 year old girls. Journal of Physical Education and Sport, 16(2), 442-451. https://doi.org/10.7752/ jpes.2016.02068

Ivashchenko, O., Khudolii, O., Iermakov, S., Chernenko, S., \& Honcharenko, O. (2018). Full factorial experiment and discriminant analysis in determining peculiarities of motor skills development in boys aged 9. Journal of 
Physical Education and Sport, 18, 1958-1965. https:// doi.org/10.7752/jpes.2018.s4289

Ivashchenko, O., \& Cieślicka, M. (2017). Discriminant analysis to assess the immediate effect of power loads in girls 7 years old. Journal of Education, Health and Sport, 7(2), 123-134. https://doi.org/10.5281/zenodo.268563

Cieślicka, M., \& Ivashchenko, O. (2017). Discriminant analysis in evaluating the features of formation cumulative effect power loads in girls 7 years old. Journal of Education, Health and Sport, 7(2), 194-206. https://doi.org/10.5281/zenodo.290226

Correa, A. A., Grima, P., \& Tort-Martorell, X. (2009). Experimentation order with good properties for $2 \mathrm{k}$ factorial designs. Journal of Applied Statistics, 36(7), 743-754. https://doi.org/10.1080/02664760802499337
Correa, A. A., Grima, P., \& Tort-Martorell, X. (2012). Experimentation order in factorial designs: new findings. Journal of Applied Statistics, 39(7), 1577-1591. https://doi.org/10.1080/02664763.2012.661706

Khudolii, O. M., \& Marchenko, S. I. (2007). Modelyuvannya rozvytku shvydkisno-sylovykh zdibnostey u shkolyariv 2-4 klasiv zasobamy rukhlyvykh ihor. Pedahohika, psykholohiya ta medyko-biolohichni problemy fizychnoho vykhovannya i sportu: naukova monohrafiya za red. prof. Yermakova SS Kharkiv: KhDADM (KhKhPI), (8), 139-142.

\title{
СИЛОВІ ЗДІБНОСТІ: ОЦІНКА ТЕРМІНОВОГО ТРЕНУВАЛЬНОГО ЕФЕКТУ СИЛОВИХ НАВАНТАЖЕНЬ У ДІВЧАТОК 7 РОКІВ
}

\author{
Худолій О.М. ${ }^{1}$, Іващенко О.В. ${ }^{2}$, Єрмаков С.С. ${ }^{3}$, Носко Ю.М. ${ }^{4}$, Марченко С.I. ${ }^{5}$ \\ ${ }_{1,2,5}$ Харківський національний педагогічний університет імені Г.С. Сковороди \\ ${ }^{3}$ Гданський університет фізичного виховання і спорту \\ ${ }^{4}$ Національний університет «Чернігівський колегіум» імені Т.Г. Шевченка \\ Реферат. Стаття: 7 с., 4 табл., 22 джерело.
}

Мета дослідження - експериментально обгрунтувати технологічні підходи до оцінки тренувальних ефектів силових навантажень у дівчаток семи років.

Матеріали і методи. У дослідженні прийняли участь дівчатка 7 років $(\mathrm{n}=40)$. Діти та їхні батьки були інформовані про всі особливості дослідження і дали згоду на участь в експерименті. Для вирішення завдань дослідження використовувалися теоретичні і емпіричні методи: аналіз і узагальнення науково-методичної літератури; моделювання, педагогічні спостереження і експеримент, методи математичного планування експерименту (ПФЕ типу $2^{\mathrm{k}}$ ).

Результати. Результати дослідження свідчать, що у запропонованій матриці плану повного факторного експерименту типа $2^{2}$ вибраний крок варіювання факторів $є$ достатнім для вивчення впливу різних режимів виконання силових вправ на динаміку TTE у дівчаток 7 років.
Висновки. Найбільший вплив на ТТЕ у дівчаток 7 років має на 1 станції (вправи для розвитку сили рук і плечового поясу) взаємодія кількості повторень у підході й інтервалу відпочинку $\left(x_{1} x_{2}\right)-$ $83 \%$, кількість повторень у підході $\left(x_{1}\right)-15 \%$; на 2 станції (вправи для розвитку сили м'язів черевного пресу) кількість повторень у підході $\left(x_{1}\right)-48,5 \%$, інтервал відпочинку $\left(x_{2}\right)-48,5 \%$; на 3 станції (вправи для розвитку сили м'язів спини - інтервал відпочинку $\left(x_{2}\right)-82 \%$; на 4 станції - вправи для розвитку сили м'язів ніг) інтервал відпочинку $\left(x_{2}\right)-92 \%$.

На 1-3 станціях для підсилення ТТЕ необхідно збільшити кількість повторень у підході й тривалість інтервалу відпочинку, на 4 станції - необхідно збільшити кількість повторень у підході й зменшити тривалість інтервалу відпочинку.

Ключові слова: дівчатка, план повного факторного експерименту, терміновий тренувальний ефект, силові навантаження. 


\title{
СИЛОВЫЕ СПОСОБНОСТИ: ОЦЕНКА СРОЧНОГО ТРЕНИРОВОЧНОГО ЭФФЕКТА СИЛОВЫХ НАГРУЗОК У ДЕВОЧЕК 7 ЛЕТ
}

\author{
Худолей О.М. ${ }^{1}$, Иващенко О.В. ${ }^{2}$, Ермаков С.С. ${ }^{3}$, Носко Ю.М. ${ }^{4}$, Марченко С.И. ${ }^{5}$ \\ ${ }_{1,2,5}$ Харьковский национальный педагогический университет имени Г.С. Сковороды \\ ${ }^{3}$ Гданский университет физического воспитания и спорта \\ ${ }^{4}$ Национальний университет «Черниговский коллегиум» имени Т.Г. Шевченко \\ Реферат. Статья: 7 с., 4 табл., 22 источника.
}

Цель исследования - экспериментально обосновать технологические подходы к оценке тренировочных эффектов силовых нагрузок у девочек семи лет.

Материалы и методы. В исследовании приняли участие девочки 7 лет $(\mathrm{n}=40)$. Дети и их родители были осведомлены обо всех особенностях исследования и дали согласие на участие в эксперименте. Для решения задач исследования использовались теоретические и эмпирические методы: анализ и обобщение научно-методической литературы; моделирование, педагогические наблюдения и эксперимент, методы математического планирования эксперимента (ПФЭ типа $2^{\mathrm{k}}$ ).

Результаты. Результаты исследования свидетельствуют, что в предложенной матрицы плана полного факторного эксперимента типа $2^{2}$ выбранный шаг варьирования факторов является достаточным для изучения влияния различных режимов выполнения силовых упражнений на динамику СТЭ у девочек 7 лет.
Выводы. Наибольшее влияние на СТЭ у девочек 7 лет имеет на 1 станции (упражнения для развития силы рук и плечевого пояса) взаимодействие количества повторений в подходе и интервала отдыха $\left(x_{1} x_{2}\right)-83 \%$, количество повторений в подходе $\left(x_{1}\right)-15 \%$; на 2 станции (упражнения для развития силы мышц брюшного пресса) количество повторений в подходе $\left(x_{1}\right)-48,5 \%$, интервал отдыха $\left(x_{2}\right)-48,5 \%$; на 3 станции (упражнения для развития силы мышц спины) - интервал отдыха $\left(x_{2}\right)-82 \%$, на 4 станции (упражнения для развития силы мышц ног) - интервал отдыха $\left(x_{2}\right)-92 \%$.

На 1-3 станциях для усиления СТЭ необходимо увеличить количество повторений в подходе и продолжительность интервала отдыха, на 4 станции необходимо увеличить количество повторений в подходе и уменьшить продолжительность интервала отдыха.

Ключевые слова: девочки, план полного факторного эксперимента, срочный тренировочный эффект, силовые нагрузки.

\section{Information about the authors:}

Khudolii O.M.: khudolii.oleg@gmail.com; http://orcid.org/0000-0002-5605-9939; Department of Theory and Methodology of Physical Education, Health and Medical Physical Culture, H. S. Skovoroda Kharkiv National Pedagogical University, Alchevskikh St, 29, Kharkiv, 61002, Ukraine.

Ivashchenko O.V.: olga@tmfv.com.ua; https://orcid.org/0000-0002-2708-5636; Department of Theory and Methodology of Physical Education, Health and Medical Physical Culture, H. S. Skovoroda Kharkiv National Pedagogical University, Alchevskikh St, 29, Kharkiv, 61002, Ukraine.

Iermakov S. S.: sportart@gmail.com; http://orcid.org/0000-0002-5039-4517; Gdansk University of Physical Education and Sport, Department of Tourism and Recreation, Kasimir Gorskogo St, 1, 80-336 Gdansk, Poland.

Nosko Yu.M.: chnpu@chnpu.edu.ua; http://orcid.org/0000-0003-1077-8206; Taras Shevchenko National University of "Chernihiv Collegium", Hetman Polubotka St, 70, Chernihiv, Chernigov region, 14000, Ukraine.

Marchenko S.I.: sport-svet1968@ukr.net; https://orcid.org/0000-0002-1013-9511; Department of Theory and Methodology of Physical Education, Health and Medical Physical Culture, H. S. Skovoroda Kharkiv National Pedagogical University, Alchevskikh St, 29, Kharkiv, 61002, Ukraine.

Cite this article as: Khudolii, O.M., Ivashchenko, O.V., Iermakov, S.S., Nosko, Yu.M., \& Marchenko, S.I. (2019). Strength Abilities: Estimation of Immediate Training Effect of Strength Loads in Girls Aged 7 Years. Teoriâ ta Metodika Fizičnogo Vihovannâ, 19(2), 98-104. https://doi.org/10.17309/tmfv.2019.2.06

Received: 10.05.2019. Accepted: 20.06.2019. Published: 25.06.2019

This work is licensed under a Creative Commons Attribution 4.0 International License (http://creativecommons.org/ licenses/by/4.0). 